\title{
Kinerja Keuangan Dan Penghematan Pajak Sebelum Dan Sesudah Revaluasi Aset
}

\author{
${ }^{1}$ Agustina Felisia \\ ${ }^{2}$ Dian Purnama Sari \\ Universitas Katolik Widya Mandala Surabaya \\ Jl Kalisari Selatan No.1, Kalisari, Kec. Mulyorejo, Surabaya, \\ Jawa Timur 60112 \\ agustina_felisia@yahoo.com
}

\begin{abstract}
Revaluation of assets is considered capable of fulfilling relevant information to investors and can improve the company's financial performance. In addition to improving financial performance, there are other studies that mention the revaluation of fixed assets may cause tax savings. Researches mostly discusse the impact of revaluation of fixed assets related to financial performance using quantitative methods, while researches looking at taxation aspects are discussed with qualitative methods. Therefore the researcher will try to connect financial performance using variables in the form of debt to equity ratio, operational profit margin, total turnover assets, and return on assets and tax savings using effective tax rate before and after revaluing fixed assets. The variable was tested using a mean difference test-MANOVA method and the sample used was a public company that revalued its fixed assets in 2013 year. The results of the study did not prove that there were differences in financial performance and tax savings before and after the company revaluing fixed assets. This has no effect because the company that revalues fixed assets is merely to meet the target of the government or actually the impact of the tax changes does not have a significant influence because there may be other impacts such as new additional costs for example appraiser fees, increased depreciation costs, all of which may make the company's profits declined and final tax must be paid by the company. Instead, the revaluation just increase the book value of fixed assets and not the fixed assets physically.

Keywords: fixed asset revaluation, financial performance, tax savings, MANOVA
\end{abstract}




\begin{abstract}
Abstrak
Revaluasi aset dianggap mampu memenuhi informasi yang relevan kepada investor dan dapat meningkatkan kinerja keuangan perusahaan. Selain meningkatkan kinerja keuangan penelitian lain menyebutkan revaluasi aset tetap menyebabkan adanya penghematan pajak. Penelitian sebelumnya banyak membahas dampak revaluasi aset tetap terkait kinerja keuangan dengan metode kuantitatif sedangkan penelitan untuk melihat dampak dari sisi perpajakan dibahas dengan metode kualitatif. Oleh karena itu peneliti akan mencoba menghubungkan apakah ada perbedaan kinerja keuangan dan penghematan pajak sebelum dan sesudah perusahaan melakukan revaluasi aset tetap. Dasar yang digunakan dengan menggunakan variabel berupa debt to equity ratio, operational profit margin, total aset turnover dan return on assets untuk mengukur kinerja keuangan dan penghematan pajak dilihat dari efective tax rate. Variabel tersebut diuji dengan menggunakan metode kuantitatif uji beda MANOVA dan sampel yang digunakan adalah perusahaan terbuka yang melakukan revaluasi aset tetap pada tahun 2013. Hasil penelitian tidak membuktikan bahwa terdapat perbedaan kinerja keuangan dan penghematan pajak sebelum dan sesudah perusahaan melakukan revaluasi aset tetap. Hal ini disebabkan oleh Perusahaan yang melakukan revaluasi aset tetap hanya sekedar untuk memenuhi target dari pemerintah atau ada dampak lain seperti adanya biaya tambahan baru seperti biaya penilai, biaya penyusutan yang meningkat sehingga menyebabkan laba perusahaan menurun serta pajak final yang harus dibayar oleh perusahaan. Revaluasi aset tetap hanya meningkatkan nilai buku aset tetap tetapi tidak menambah fisik aset tetapnya.
\end{abstract}

Kata kunci: revaluasi aset tetap, kinerja keuangan, penghematan pajak, MANOVA.

\title{
PENDAHULUAN
}

Revaluasi aset tetap merupakan suatu penilaian kembali aset tetap sehingga nilai aset tetap suatu perusahaan menjadi lebih tinggi dan revaluasi juga merupakan sarana yang bisa digunakan sebagai dasar untuk menyeimbangkan komposisi antara modal dan utang (Manihuruk dan Farahmita, 2015). Terkait revaluasi aset tetap sebenarnya diperbolehkan 
sejak Indonesia mengadopsi IFRS (International Financial Reporting Standard) pada tahun 2007 dimana pengakuan aset tetap menurut Pernyataan Standar Akuntansi Keuangan (PSAK) No.16 memberikan pilihan bagi perusahaan untuk menggunakan metode revaluasi atau metode biaya (cost). Pemerintah juga telah memfasilitasi masalah revaluasi aset tersebut sejak tahun 2008 yaitu melalui PMK Nomor: 79/PMK.03/2008 tentang Penilaian Kembali Aset Tetap Perusahaan Untuk Tujuan Perpajakan. Akan tetapi dengan dikeluarkannya Standar Akuntansi Keuangan dan PMK tersebut sejak tahun 2008, tidak membuat banyak perusahaan yang melakukan revaluasi aset tetap. Alasan utama karena jika menggunakan model revaluasi untuk tujuan perpajakan akan berdampak pada dikenakannya Pajak Penghasilan atas selisih lebih revaluasi aset tetap dan nilainya cukup besar dan tambahan biaya untuk penilai aset (Suyani, 2017). Oleh karena itu pada tahun 2015, Menteri Keuangan menindaklanjuti hal tersebut dengan mengeluarkan pengganti PMK Nomor: 79/PMK.03/2008 dimana PMK tersebut telah diperbaharui dengan dikeluarkannya PMK 191/PPMK.010/2015 yang berisi perubahan pada tarif pajak yang dikenakan dari surplus revaluasi aset tetap. Perubahan terkait pajak penghasilan yang bersifat final dimana pada awalnya dikenakan tarif 10\% dirubah untuk tahun 2015 dan 2016, perusahaan dapat menikmati tarif khusus 3\% jika WP telah memperoleh penetapan penilaian kembali aktiva tetap dan melunasi pajaknya sampai 31 Desember 2015, 4\% untuk pelunasan dari 1 Januari sampai 30 Juni 2016, dan 6\% untuk pelunasan hingga 31 Desember 2016 yang dikenakan atas selisih lebih nilai aset tetap hasil penilaian kembali.

Penelitian ini menjadi menarik karena setelah pemerintah mengeluarkan peraturan menteri keuangan No. 191/PMK.010/2015 yang memberikan potongan tarif pajak terhadap pelaksanaan revaluasi aset tetap, dimana banyak perusahaan yang memanfaatkan kesempatan ini untuk melakukan revaluasi atas aset tetapnya. Revaluasi aset yang dilakukan diyakini juga akan menyebabkan pencatatan pembukuan perusahaan terhadap aset tetap beralih dari model biaya (historis) ke model revaluasi (fair value). Hal ini dapat dilihat dari tahun 2013 sampai tahun 2017, terdapat peningkatan jumlah perusahaan yang melakukan revaluasi aset tetap terutama di tahun 2015 sejak dikeluarkannya PMK 191/PPMK.010/2015 tersebut dan jika dibandingkan dengan jumlah perusahaan terbuka periode 31 Desember 2015 yang berjumlah 508 perusahaan maka tergolong sedikit perusahaan yang memanfaatkan kebijakan pemerintah tersebut.

Selanjutnya menurut Djohan (2015) dalam salah satu sesi seminar yang diselenggarakan dalam rangka ulangtahun IAI ke-58 membahas Asset Revaluation: The Implication on Tax, Accounting, and Performance 
Management. "Revaluasi itu tujuannya untuk memperbaiki neraca. Tentu saja ada harga yang harus dibayarkan ketika melakukan revaluasi itu. Dalam menghitung RoA (Return on Asset) misalnya, ketika pembaginya makin besar, angka pengembalian terlihat semakin kecil. Tapi DER (Debt to Equity Ratio) akan terlihat semakin baik,". Dengan peningkatan rasio maka pihak eksternal perusahaan tidak hanya berhenti pada kreditor namun ada juga pihak eksternal perusahaan lainnya yaitu investor. Dalam hal ini, investor memiliki kecenderungan untuk melakukan analisis terhadap kinerja perusahaan berdasarkan rasio keuangan yang berfokus pada ekuitas perusahaan. Rasio tersebut digunakan oleh investor untuk mengukur tingkat pertumbuhan perusahaan. Rasio ini memberikan asumsi kepada investor sejauh mana perusahaan diakui oleh banyak investor lainnya berdasarkan harga pasar perusahaan. Rasio ini membandingkan ekspetasi investor mengenai keberlanjutan perusahaan dengan nilai ekuitas tercatat perusahaan. Kinerja keuangan perusahaan dinilai dengan menggunakan alat formal berupa rasio keuangan yang dimaksud antara lain terkait dengan rasio aktivitas, rasio solvabilitas dan rasio profitablitas antara lain debt to equity ratio, operational profit margin, total aset turnover, return on assets.

Terkait dengan kinerja keuangan perusahaan ada beberapa hasil penelitian yaitu penelitian Aboody (1999) menyebutkan bahwa dengan melakukan revaluasi aset tetap secara signifikan berhubungan positif dengan perubahan dalam kinerja keuangan masa depan, diukur dengan operating income ratio dan cash from operations. Penelitian Missioner-Piera (2007) menyebutkan pada perusahaan di Swiss menghasilkan hal yang sama yaitu leverage berpengaruh positif terhadap keputusan melakukan revaluasi aset tetap dimana perusahaan yang memiliki leverage tinggi akan memilih metode revaluasi karena akan menurunkan tingkat utang, misalnya di Australia (Brown et al, 1992); dan di Swiss (Piera, 2007); perusahaan dengan growing debt akan merevaluasi aset (Barac dan Sodan, 2011). Penelitan Seng dan Su (2010) berbeda dimana tidak menemukan hubungan leverage dengan revaluasi aset tetap. Revaluasi aset dapat dijadikan sebagai alat untuk menurunkan rasio debt to equity untuk menghindari biaya kegagalan utang (debt hypothesis) dan juga dapat digunakan sebagai sinyal adanya pertumbuhan perusahaan (Azouzi dan Jarboui, 2012).

Revaluasi aset tetap juga berkaitan dengan penghematan pajak. Penghematan pajak merupakan suatu upaya yang dilakukan perusahaan untuk meminimumkan pajak yang harus ditanggung dengan cara yang legal, yaitu dengan cara memanfaatkan kelemahan yang ada pada peraturan perundang-undangan. Penghematan pajak dapat diukur dengan effective tax rate (ETR). ETR merupakan salah satu alat untuk mengukur seberapa besar kemungkinan perusahaan melakukan tax avoidance karena ETR 
menggambarkan kegiatan penghematan pajak dengan cara melihat jumlah pajak yang dibayar. Hal ini didukung oleh penelitian Annisa (2017) menemukan bahwa Leverage yang diproksikan dengan Debt to Equity Ratio (DER) berpengaruh terhadap penghematan pajak yang dilakukan perusahaan. Musyarrofah (2017), menyebutkan bahwa semakin tinggi leverage (DER) akan semakin tinggi pula effective tax rate pada perusahaan. Hal ini disebabkan adanya peningkatan biaya bunga diikuti dengan peningkatan biaya pajak. Perusahaan menggunakan utang yang diperoleh untuk keperluan investasi sehingga menghasilkan pendapatan atau laba yang lebih besar. Hal ini membuat laba yang diperoleh perusahaan naik dan mempengaruhi kenaikan beban pajak yang ditanggung perusahaan. Oleh karena itu, leverage dapat berdampak pada effective tax rate perusahaan menjadi lebih efektif.

Menurut Fachrina (2017) dan Sherlita (2015), revaluasi aset tetap terkait dengan PMK 191/PPMK.010/2015 sebenarnya merupakan salah satu strategi terkait perencanan pajak. Revaluasi aset tetap menyebabkan nilai aset meningkat sehingga berkaitan dengan beban penyusutan dalam jangka waktu yang panjang. Beban penyusutan yang semakin besar, menyebabkan laba yang diperoleh perusahaan semakin kecil dan pajak yang terutang dan yang dibayarkan perusahaan juga semakin kecil. Hal ini sesuai dengan penelitian Wijaya dan Supandi (2017) bahwa revaluasi aset tetap untuk tujuan perpajakan dapat meningkatkan laba bersih, aset, dan ekuitas, revaluasi aset juga dapat memberikan manfaat berupa berkurangnya pajak penghasilan untuk tahun setelah revaluasi serta manfaat ekonomi lainnya, yaitu performa keuangan perusahaan yang meningkat. Revaluasi aset pada dasarnya bertujuan untuk meningkatkan nilai aset bersih atau ekuitas perusahaan itu sendiri secara keseluruhan. Kenaikan nilai aset bersih juga menyebabkan leverage perusahaan meningkat. Hal ini digunakan oleh perusahaan jika perusahaan berkeinginan untuk mengajukan pinjaman yang lebih besar ke bank dalam rangka keperluan ekspansi, dan perusahaan akan menanggung biaya bunga yang besar sehingga laba perusahaan akan menurun. Penurunan laba perusahaan akibat biaya pinjaman yang dapat diakui sebagai beban dan beban penyusutan yang semakin besar akibat meningkatnya nilai aset yang telah direvaluasi.

Berdasarkan fenomena yang telah dipaparkan di atas, banyak penelitian terdahulu yang mengkaitkan revaluasi aset tetap hanya dengan faktor-faktor kinerja keuangan berupa leverage yang mempengaruhi perusahaan melakukan revaluasi aset tetap dan dengan menggunakan metode kuantitatif. Sedangkan penelitian yang mengkaitkan revaluasi dengan penghematan pajak hanya dibahas secara kualitatif pada perusahaan yang melakukan revaluasi aset tetap. Sampai saat ini belum banyak penelitan yang juga membahas kaitan revaluasi aset tetap sesuai dengan 
PMK 191 dikaitkan dengan kinerja keuangan dan penghematan pajak dan dibahas dengan menggunakan metode kuantitatif uji beda. Oleh karena itu peneliti akan menganalisa perbedaan sebelum dan sesudah perusahaan melakukan Revaluasi Aset Tetap dilihat dari kinerja keuangan dan penghematan pajak Perusahaan dengan menggunakan metode kuantitatif uji beda MANOVA.

\section{LANDASAN TEORI}

Revaluasi aset sebenarnya sama dengan penyajian kembali atas nilai buku aset sehingga mendekati nilai saat ini atau penilaian kembali aset tetap. Alasan yang mendasari keputusan dari revaluasi aset tetap adalah agar laporan keuangan mencerminkan nilai wajar (fair value). Revaluasi akan menyajikan kembali nilai buku aset tetap agar mendekati nilai sekarangnya (Brown et al, 1992). Tyas (2009, dalam penelitian Yulistia 2015) menyebutkan revaluasi aset tetap dapat berupa upward revaluation dan downward revaluation. Penyajian kembali nilai buku melebihi net current value disebut upward sebaliknya revaluasi downward jika net current value dibawah nilai bukunya. Upward dapat meningkatkan nilai ekuitas pemegang saham dan nilai aset tetap dan sebaliknya dapat mengakibatkan menurunnya rasio leverage (kemampuan perusahaan untuk memenuhi semua utangnya) seperti rasio debt to equity dan debt to total asset. Rasio keuangan yang membaik akan meyakinkan kreditur bahwa perusahaan mampu memenuhi kewajibannya. Menurut Whittered dan Chan (1992) menyebutkan perusahaan dengan tingkat utang tinggi akan merevaluasi aset tetap untuk mentaati perjanjian utang dan dapat melanjutkan peminjaman.

Perusahaan dapat melakukan penilaian kembali aset tetap perusahaan untuk tujuan perpajakan, Hal ini didukung oleh pemerintah melalui Pasal 1 ayat (1) Peraturan Menteri Keuangan Nomor 191/PMK.010/2015, menyebutkan wajib pajak dapat melakukan penilaian kembali aset tetap untuk tujuan perpajakan dengan mendapatkan perlakuan khusus apabila permohonan penilaian kembali diajukan kepada Direktur Jenderal Pajak. PMK tersebut memberikan perlakuan khusus tersebut berupa pajak penghasilan yang bersifat final dengan tarif sebesar 3\% untuk permohonan yang diajukan sejak berlakunya PMK Nomor 191/PMK.010/2015 sampai dengan tanggal 31 Desember 2015, 4\% untuk permohonan yang diajukan sejak 1 Januari 2016 sampai dengan tanggal 30 Juni 2016, atau 6\% untuk permohonan yang diajukan sejak 1 Juli 2016 sampai dengan tanggal 31 Desember 2016.

Selain berdampak aturan pemerintah yang mengeluarkan peraturan mengenai penurunan tarif pajak final atas selisih revaluasi aset tetap, revaluasi aset tetap dianggap berdampak terhadap kinerja keuangan 
perusahaan. Kinerja keuangan merupakan suatu alat formal yang digunakan oleh sebuah perusahaan untuk mengevaluai apakah sebuah perusahaan sudah efisien dan efektifitas dalam menjalankan aktivitas perusahaan dari waktu ke waktu. Alat yang digunakan untuk mengukur kinerja biasanya adalah rasio keuangan. Analisis rasio keuangan menurut Warsindi dan Bambang (2000) dalam Fahmi (2014) merupakan suatu instrumen analisis prestasi perusahaan yang menjelaskan berbagai hubungan dan indikator keuangan, yang dilihat dari perubahan dalam kondisi keuangan atau prestasi operasi perusahaan di masa lalu dan mengambarkan trend perubahan tersebut dan kemudian menunjukkan risiko dan peluang yang melekat pada perusahaan yang bersangkutan. Sedangkan menurut Horne dan Wachowicz (2013) menyebutkan "To evaluate the financial condition and performance of a firm, the financial analyst needs certain yardstick. The yardstick frequently used is a ratio, index, relating two pieces of financial data of to each other" dan menurut Gitman (2012) menyebutkan bahwa "Ratio analysis involves methods of calculating and interpreting financial ratio to asses the firm's performance. The basic inputs to ratio analysis are the firm's income statement and balance sheet" Dari pengertian diatas maka dapat disimpulkan bahwa rasio keuangan dan kinerja keuangan berhubungan erat.

Seorang investor akan menggunakan rasio keuangan sebagai dasar analisis dan dapat memberikan kemudahan dalam proses pengambilan sebuah keputusan terutama keputusan terkait langkah apakah perusahaan akan melakukan revaluasi aset tetap atau tidak. Rasio yang digunakan terkait untuk menganalisa laporan keuangan perusahaan terutama untuk perusahaan yang melakukan revaluasi aset tetap adalah rasio Debt to Equity dimana rasio ini merupakan rasio leverage yang memberi gambaran mengenai jaminan yang dapat diberikan oleh perusahaan mengenai pemenuhan kewajiban dengan menggunakan ekuitas, bahkan dalam kondisi perusahaan yang paling buruk sekalipun. Semakin kecil rasio ini, maka jaminan yang diberikan perusahaan dengan menggunakan ekuitas untuk menyelesaikan utang semakin besar.Rasio debt to equity ratio (DER) digunakan untuk mengukur tingkat leverage (penggunaan utang) terhadap total ekuitas yang dimiliki oleh perusahaan. Rasio ini diukur dengan cara membandingkan antara debts terhadap total equity. Debt ratio yang tinggi mempunyai dampak yang buruk terhadap kinerja perusahaan, karena tingkat utang semakin tinggi, yang berarti beban bunga akan semakin besar sehingga dapat mengurangi keuntungan. Sebaliknya, tingkat debt ratio yang kecil menunjukkan kinerja yang semakin baik, karena menyebabkan tingkat pengembalian yang semakin tinggi. Semakin besar utang, semakin besar risiko yang ditanggung perusahaan. Oleh sebab itu perusahaan yang tetap mengambil utang sangat tergantung pada biaya relatif. Biaya utang lebih kecil daripada dana ekuitas. Dengan menambahkan utang ke dalam 
neracanya, perusahaan secara umum dapat meningkatkan profitabilitasnya, yang kemudian menaikkan harga sahamnya, sehingga meningkatkan kesejahteraan para pemegang saham dan membangun potensi pertumbuhan yang lebih besar.

Rasio kedua adalah Operating Profit Margin (Operating Income) dimana rasio ini merupakan salah satu indikator untuk mengetahui gambaran dari kinerja perusahaan. Kaitannya dengan Peraturan Menteri Keuangan Republik Indonesia Nomor 191/PMK.010 /2015 tentang revaluasi, perusahaan yang merevaluasi aset tetapnya akan mendapatkan nilai aset yang lebih tinggi. Nilai aset yang lebih tinggi ini dapat digunakan oleh perusahaan untuk memperoleh tambahan pinjaman hutang dan menambah modal dengan menerbitkan saham baru. Adanya tambahan modal dan hutang maka perusahaan dapat memperbesar bisnis dan diharapkan ada peningkatan operating profit margin.

Rasio ketiga adalah rasio Total Assets Turnover yang menunjukan tingkat aktivitas perusahaan dimana melihat sejauh mana keseluruhan aset yang dimiliki oleh perusahaan terjadi perputaran secara efektif atau mengukur efisiensi penggunaan aset untuk menghasilkan penjualan. Peraturan Menteri Keuangan Republik Indonesia Nomor 191/PMK.010/2015 mendorong perusahaan melakukan revaluasi. Perusahaan yang merevaluasi asetnya akan diasumsikan mengalami peningkatan nilai aset meskipun peningkatan nilai tersebut tidak diikuti peningkatan secara fisik. Rasio aktivitas dilibatkan guna mengetahui apakah terjadi perubahan aktivitas perusahaan setelah dilakukannya revaluasi. Semakin tinggi tingkat perputaran aset maka pendapatan yang akan diperoleh perusahaan juga akan naik (Fahmi, 2014).

Rasio yang terakhir yang berpengaruh adalah rasio Return on Assets (ROA) dimana rasio ini merupakan salah satu dasar penilaian kuantitatif terhadap profitabilitas perusahaan. ROA sangat tergantung terhadap nilai aset suatu perusahaan. ROA bertujuan untuk melihat sejauh mana investasi yang telah ditanamkan mampu memberikan pengembalian keuntungan sesuai dengan yang diharapkan atau dengan kata lain ROA adalah rasio yang mengukur seberapa efisien suatu perusahaan dalam mengelola asetnya untuk menghasilkan laba selama suatu periode. ROA membantu manajemen untuk melihat seberapa baik suatu perusahaan mampu mengkonversi investasinya pada aset menjadi keuntungan atau laba (profit). ROA sering juga disebut sebagai imbal hasil investasi (return on investment) bagi suatu perusahaan karena pada umumnya aset modal (capital assets) seringkali merupakan investasi terbesar bagi kebanyakan perusahaan. Dengan kata lain, uang atau modal diinvestasikan menjadi aset modal dan tingkat 
pengembaliannya atau imbal hasilnya diukur dalam bentuk laba atau keuntungan (profit) yang diperolehnya (Fahmi, 2014).

Dalam penelitian Taufik dan Hanif (2017) menyebutkan bahwa ROA atau hasil dari pengembalian dari harta merupakan perbandingan antara laba bersih dengan jumlah harta rata-rata, rasio tersebut merupakan ukuran tingkat profitabilitas ditinjau dari jumlah harta yang dimilikinya. ROA merupakan indikator besarnya pendapatan terhadap aset yang digunakan. Bila meningkat berarti menunjukkan peningkatan efisiensi penggunaan aset. ROA memiliki beberapa manfaat yang antara lain: (1) Jika perusahaan telah menjalankan praktik akuntansi dengan baik maka dengan analisis ROA dapat diukur efisiensi penggunaan modal yang menyeluruh dan sensitif terhadap setiap hal yang mempengaruhi keadaan keuangan perusahaan, (2) Dapat diperbandingkan dengan rasio industri sehingga dapat diektahui posisi perusahaan terhadap industri. Hal ini merupakan salah satu langkah dalam perencanaan strategi, (3) Selain berguna untuk kepentingan control, analisis ROA juga berguna untuk kepentingan perencanaan.

Penghematan pajak merupakan suatu proses terkait pengendalian tindakan agar perusahaan terhindar dari konsekuensi pengenaan pajak yang tidak dikehendaki (Suandy, 2011). Penghematan pajak bukan merupakan suatu pelanggaran hukum yang dilakukan tetapi lebih mengarah bagaimana perusahaan harus mengatur tindakan agar perusahaan memperoleh penghematan pajak atau dalam arti jumlah pajak yang dibayar berkurang. Banyak cara yang bisa dilakukan oleh perusahaan untuk melakukan tax avoidance dan salah satu yang diyakini adalah dengan peningkatan leverage (Musyarrofah, 2017). Peningkatan leverage bisa dilakukan salah satunya dengan melakukan revaluasi aset tetap. Pengukuran perencanaan pajak yang efektif dapat dilakukan dengan menggunakan tarif pajak efektif (effective tax rate/ETR).

Tarif pajak efektif merupakan alat yang digunakan untuk mengukur keberhasilan suatu perusahaan dalam pengendalian effective tax planning dan merupakan konsep laba akuntansi yang mempengaruhi laporan arus kas perusahaan. Menurut Soenarno (2013), dua pendekatan yang digunakan untuk menghitung tarif pajak efektif yaitu pendekatan tradisional menggunakan rekonsiliasi pajak. Rekonsiliasi ini menghitung perbedaan antara beban pajak penghasilan menurut laporan akuntansi dan beban pajak kini yang diperoleh dari perhitungan tarif sesuai undang-undang yang berlaku. Pendekatan kedua adalah analisa strategi tarif pajak, dengan cara mendefinisikan terlebih dahulu langkah perencanaan pajak yang dilakukan perusahaan misalnya pembayaran bunga, royalty, transfer pricing dan management fee. Setelah masing-masing strategi dilakukan maka dihitung laba rugi yang dihasilkan. Net benefit dari strategi tersebut dikenakan tarif 
pajak yang berlaku lalu dibagi dengan laba sebelum pajak maka diperoleh tarif pajak efektif.

Tarif pajak efektif bermanfaat bagi perusahaan untuk mengetahui sejauh mana perusahaan mampu memanage sistem perpajakan yang berlaku sehingga alat ini penting bagi para pembuat keputusan terkait penghematan pajak. Jadi tarif pajak efektif berguna bagi perusahaan untuk melihat berapa pajak yang sebenarnya dibayar apakah lebih besar atau lebih kecil dari tarif yang ditetapkan berdasarkan laba komersial sebelum pajak perusahaan tersebut.

\section{DEFINISI OPERASIONAL DAN PENGUKURAN VARIABEL}

Variabel yang digunakan dalam penelitian ini ada 5 yaitu debt to equity ratio, operational profit margin, total aset turnover, return on assets dan efective tax rate yang mendorong perusahaan untuk melakukan revaluasi aset tetap. Penelitian ini berfokus pada revaluasi aset kinerja keuangan dan penghematan pajak yang mendasari perusahaan melakukan revaluasi aset tetap.

Tabel 1. Variabel dan Definisi Variabel

\begin{tabular}{|c|c|c|c|}
\hline No. & Var & Definisi operasional & Rumus \\
\hline \multicolumn{4}{|c|}{ Kinerja Keuangan } \\
\hline \multirow[t]{2}{*}{1} & \multirow[t]{2}{*}{ DER } & \multirow{2}{*}{$\begin{array}{l}\text { Rasio untuk mengukur besarnya utang } \\
\text { yang ditanggung oleh modal sendiri }\end{array}$} & Total utang \\
\hline & & & Total ekuitas \\
\hline \multirow[t]{2}{*}{2} & \multirow[t]{2}{*}{ OPM } & \multirow{2}{*}{$\begin{array}{l}\text { Rasio untuk mengukur kemampuan } \\
\text { perusahaan dalam menghasilkan laba } \\
\text { operasional dari penjualan bersih }\end{array}$} & Laba usaha \\
\hline & & & Penjualan \\
\hline \multirow[t]{2}{*}{3} & \multirow[t]{2}{*}{ TATO } & \multirow{2}{*}{$\begin{array}{l}\text { Rasio untuk mengukur seberapa efektif } \\
\text { aset perusahaan mampu menghasilkan } \\
\text { penjualan }\end{array}$} & - Penjualan \\
\hline & & & Total aset \\
\hline \multirow[t]{2}{*}{4} & \multirow[t]{2}{*}{$\mathrm{ROA}$} & \multirow{2}{*}{$\begin{array}{l}\text { Rasio untuk mengukur kemampuan } \\
\text { manajer dalam mengukur aktiva } \\
\text { seoptimal mungkun sehingga mencapai } \\
\text { laba bersih yang di inginkan }\end{array}$} & Laba bersih setelah pajak \\
\hline & & & Total aset \\
\hline \multicolumn{4}{|c|}{ Penghematan Pajak } \\
\hline \multirow[t]{2}{*}{5.} & \multirow[t]{2}{*}{ ETR } & \multirow{2}{*}{$\begin{array}{l}\text { Rasio ini mengukur tingkat pajak } \\
\text { efektif perusahaan }\end{array}$} & $=$ Beban pajak penghasilan \\
\hline & & & $=\overline{\text { Laba sebelum pajak }}$ \\
\hline
\end{tabular}

\section{ANALISIS DATA}

Dalam menganalisa data ini peneliti menggunakan metode analisis kuantitatif eksplorasi. Adapun teknik analisis statistik yang digunakan adalah uji MANOVA dengan menggunakan progam SPSS 23 berupa Uji 
Beda. Data yang diperoleh dari hasil pengukuran kemudian dianalisis untuk mengetahui apakah hasilnya sesuai dengan hipotesis yang diharapkan. Peneliti menggunakan uji Multivariate Analysis of Variance atau MANOVA, pada uji MANOVA jumlah variabel dependen lebih dari satu (metrik atau interval) dan variabel independen jumlahnya dapat satu atau lebih (non-metrik atau nominal). Uji multivariate digunakan untuk menguji apakah setiap faktor mempengaruhi grup variabel dependen. MANOVA merupakan suatu teknik statistik yang digunakan untuk menghitung pengujian signifikansi perbedaan rata-rata secara bersamaan antara kelompok untuk dua atau lebih variabel dependen/terikatnya. Teknik ini bermanfaat untuk menganalisis banyak variabel (lebih dari dua) yang berskala interval dan rasio.

Dalam penelitian ini, yang akan diteliti menggunakan uji MANOVA adalah pengaruh revaluasi aset tetap terhadap kinerja keuangan Perusahaan dan penghematan pajak. Setelah diperoleh nilainya, adapun kaidah menentukan hasil uji berdasarkan yang berarti: (1) Jika Taraf Signifikasi > nilai $\quad 0.05$ maka tidak terdapat perbedaan, yang berarti rata-rata kedua perlakuan mempunyai kesamaan secara signifikan, dan (2) Jika Taraf Signifikasi < nilai 0.05 maka terdapat perbedaan, yang berarti rata-rata kedua perlakuan berbeda secara signifikan. Uji MANOVA akan dilakukan denganbantuan SPSS.

\section{HASIL PENELITIAN}

Populasi dalam penelitian ini adalah seluruh perusahaan yang terdaftar di Bursa Efek Indonesia pada tahun 2013 sampai 2017 kecuali sektor perbankan dan asuransi. Perusahaan yang terdaftar di Bursa Efek Indonesia pada tahun 2013 sampai 2017 berjumlah sebanyak 508 perusahaan yang diambil dari publikasi laporan keuangan perusahaan yang terdapat dalam www.idx.co.id. Metode pemilihan sampel yang digunakan adalah purposive sampling, yaitu metode berdasarkan pertimbangan dan kriteria tertentu. Penyeleksian perusahaan yang memenuhi kriteria populasi sebanyak 62 perusahaan yang melakukan revaluaasi aset tetap pada tahun 2013.

Berdasarkan hasil uji beda yang diajukan dalam penelitian ini menggunakan alat analisis Multivariate Analysis of Variance (MANOVA) dengan uji Multivariate dan uji Tests of Between Subjects Effects. Teknik ini bermanfaat untuk menganalisis variabel - variabel dependen lebih dari dua yang berskala interval atau rasio. Dengan menggunakan tingkat Asymp. Sig.0,05, jika hasil uji Tests of Between Subjects Effects yang didapatkan signifikan kurang dari yang ditetapkan $(\alpha=5 \%)$ maka variabel independen tersebut berpengaruh signifikan terhadap variabel dependen. Berikut adalah hasil dari uji Tests of Between Subjects Effects. 
Tabel 2. Uji Multivariate Test

\begin{tabular}{|c|c|c|c|c|}
\hline \multirow{2}{*}{$\begin{array}{l}\text { Effect } \\
\text { Intercept }\end{array}$} & & Value & $\mathbf{F}$ & Sig. \\
\hline & Pillai's Trace & 866 & $107,475^{\mathrm{b}}$ & ,000 \\
\hline \multirow{6}{*}{ RA } & Wilks' Lambda & ,134 & $107,475^{\mathrm{b}}$ & ,000 \\
\hline & Hotelling's Trace & 6,474 & $107,475^{\mathrm{b}}$ & 000 \\
\hline & Roy's Largest Root & 6,474 & $107,475^{\mathrm{b}}$ & 000 \\
\hline & Pillai's Trace &, 057 & ,490 & 895 \\
\hline & Wilks' Lambda & 944 &, $490^{\mathrm{b}}$ & 895 \\
\hline & Hotelling's Trace & 060 & 489 & 896 \\
\hline & Roy's Largest Root & 054 & $916^{\mathrm{c}}$ & 475 \\
\hline
\end{tabular}

Berdasarkan tabel di atas diketahui nilai sig yang diuji dengan Pillai's Trace, Wilks' Lambda, Hotelling's Trace dan Roy's Largest Root seluruhnya menunjukkan sig >0,05 maka Ho diterima, yang artinya secara bersama-sama tidak terdapat perbedaan antara kinerja perusahaan dan penghematan pajak sebelum dan sesudah revaluasi asset pada perusahaan.

Tabel 3. Tests of Between-Subjects Effects

\begin{tabular}{llrr}
\hline Source & $\begin{array}{l}\text { Dependent } \\
\text { Variabel }\end{array}$ & F & \multicolumn{1}{c}{ Sig. } \\
\hline RA & DER &, 310 &, 735 \\
& OPM &, 109 &, 897 \\
& TATO &, 559 &, 574 \\
& ROA &, 112 &, 894 \\
& ETR & 1,442 &, 242 \\
\hline
\end{tabular}

Sumber: Output SPSS 23

Pengujian hipotesis dilakukan dengan cara membandingkan antara tingkat signifikansi (sig.) dengan tingkat kesalahan 5\%. Berdasarkan tabel diatas dapat diinterpretasikan bahwa untuk semua variabel Debt to Equity Ratio, Operational Profit Margin, Total Asset Turnover, Return on Assets dan Tarif Pajak Efektif menunjukkan nilai signifikansi lebih besar dari $0,05 \%$ yang artinya tidak ada perbedaan rasio tersebut di atas yang dipengaruhi oleh sebelum dan sesudah revaluasi asset.

\section{PEMBAHASAN}

Tujuan penelitian adalah menilai kinerja keuangan dan penghematan pajak sebelum dan sesudah perusahaan melakukan revaluasi aset tetap. Revaluasi aset menurut penelitian sebelumnya menyatakan bahwa revaluasi akan meningkatkan kinerja keuangan perusahaan karena dengan revaluasi 
terdapat peningkatan pada ekuitas dan aset tetap perusahaan. Selain peningkatan kinerja keuangan revaluasi aset tetap berdampak pada penghematan pajak karena dampak penyusutan atas aset tetap tersebut. Akan tetapi berdasarkan hasil analisis uji MANOVA dalam penelitian ini menunjukkan bahwa analisis kinerja keuangan dengan menggunakan proxi Operating Margin Ratio (OPM), Debt to Equity Ratio (DER), Total Assets Turnover (TATO), Return on Assets (ROA) dan penghematan pajak dengan menggunakan proxi tarif pajak efektif tidak menemukan perbedaan sebelum dan sesudah revaluasi aset tetap.

Kinerja keuangan berupa debt to equity ratio menunjukkan bahwa tidak ada perbedaan sebelum dan sesudah perusahaan melakukan revaluasi aset tetap. Hasil penelitian ini sejalan dengan hasil penelitian yang dilakukan oleh Yulistia, Fauziati, Minovia, Khairiti (2012) yang menemukan bahwa revaluasi aset tetap gagal membuktikan bahwa keputusan revaluasi aset tetap memiliki pengaruh terhadap variabel leverage dan penelitian Seng dan Su (2010), juga menyebutkan tidak ditemukan adanya pengaruh signifikan antara leverage dengan keputusan revaluasi aset. Pada penelitian Seng dan Su (2010) dijelaskan bahwa penggunaan revaluasi aset dengan tujuan untuk menyesuaikan kontrak akan menyebabkan timbulnya biaya lebih dimasa mendatang bagi perusahaan dan menurunnya kredibilitas manajemen perusahaan. Dapat disimpulkan bahwa revaluasi aset tetap tidak menyebabkan dampak terhadap kenaikan pada debt to equity ratio perusahaan. Hal ini membuktikan juga bahwa perusahaan bisa menaikkan equity bukan hanya dengan melakukan revaluasi aset tetap tetapi mungkin dengan menawarkan saham ke masyarakat dan memiliki biaya yang lebih murah dibandingkan dengan melakukan revaluasi aset tetap.

Revaluasi aset juga tidak berpengaruh terhadap rasio profitabilitas baik untuk operational profit margin dan return on assets. Hal ini terbukti bahwa dengan melakukan revaluasi aset tetap tidak membuat perusahaan memperoleh peningkatan penjualan maupun peningkatan operational profit margin karena revaluasi aset tetap sebenarnya tidak berdampak pada kinerja perusahaan tetapi hanya mengambarkan penyajian laporan keuangan yang menampilkan nilai wajar aset perusahaan saja dimana perubahan pada nilai wajar aset tersebut tidak menambah kenaikan pada laba bersih perusahaan. Nilai aset yang lebih tinggi tidak dapat menjadikan jaminan perusahaan untuk memperoleh tambahan pinjaman hutang dan menambah modal sehingga penjualan akan meningkat tetapi sebaliknya dengan revaluasi aset tetap menyebabkan beban penyusutan atas aset tersebut meningkat sehingga menyebabkan laba perusahaan mengalami penurunan. 
Revaluasi aset tidak berpengaruh juga terhadap total asset turnover. Total Asset Turnover (TATO) merupakan ukuran efektivitas pemanfaatan aset dalam menghasilkan penjualan. Semakin tinggi rasio ini berarti semakin efektif pengelolaan seluruh aset yang dimiliki perusahaan. Dari hasil analisa menunjukkan hal yang sama bahwa peningkatan aset tidak didukung dengan upaya perusahaan meningkatan penjualan karena sebenarnya revaluasi hanya meningkatkan nilai aset tetapi tidak menambah jumlah aset yang dimiliki. Revaluasi aset tidak menyebabkan kapasitas produksi perusahaan bertambah tetapi ada konsekuensi administrasi serta biaya untuk jasa penilai (appraiser) yang meningkat yang harus dibayar oleh perusahaan.

Berdasarkan hasil analisis uji MANOVA dalam penelitian ini juga menyimpulkan bahwa revaluasi aset tidak berpengaruh terhadap penghematan pajak yang di proxikan dengan tarif pajak efektif. Peningkatan revaluasi aset tetap akan menyebabkan nilai buku aset tetap meningkat dan berpengaruh pada peningkatan biaya penyusutan. Biaya penyusutan berpengaruh pada penurunan laba bersih perusahaan sehingga seharusnya beban pajak yang dibayarkan perusahaan lebih kecil akibat penurunan laba perusahaan. Laba perusahaan setelah aset tetap mengalami revaluasi lebih rendah dibandingkan jika aset tetap tersebut tidak direvaluasi tetapi hal yang terjadi adalah penurunan beban pajak tersebut tidak signifikan karena aturan pajak penyusutan untuk aset revaluasi dianggap memiliki umur masa manfaat yang baru, sehingga dampak penyusutan mungkin tidak bisa hanya dilihat 1-2 tahun saja karena efek dampak penyusutan adalah jangka panjang sesuai dengan umur ekonomis aset tersebut.

Hasil penelitian ini juga menunjukkan bahwa tidak ada pengaruh perusahaan yang melakukan revaluasi karena ada faktor lain yaitu sebagian perusahaan yang melakukan revaluasi aset tetap adalah hanya dilakukan pada aset tetap tanah saja sehingga tidak ada dampak pada beban penyusutan. Selain itu apabila ditelusuri lebih detail, suatu hal yang menyebabkan revaluasi aset tetap tidak mampu memberikan penghematan pajak adalah karena kebijakan revaluasi yang dilakukan perusahaan hanya pada beberapa aset yang dimiliki perusahaan saja atau bisa disebut dengan revaluasi parsial. Hal ini menyebabkan revaluasi aset tetap tidak memberikan dampak signifikan terhadap penghematan pajak. Aset tetap berupa tanah memiliki nilai revaluasi cukup besar dan hanya berdampak pada pajak final saja tetapi tidak berdampak pada tarif pajak efektif. Revaluasi atas aset selain tanah menyebabkan kenaikan beban penyusutan lebih besar dan kenaikan beban pajak penghasilan final tetapi penurunan pajak penghasilan, tetapi karena komponen tersebut tidak memiliki dampak yang material diantara komponen laba rugi lain maka hal tersebut tidak 
menyebabkan laba bersih perusahaan meningkat. Tetapi jika pihak kreditor menyetujui tambahan pendanaan baru kepada perusahaan mungkin perusahaan butuh waktu 2-3 tahun untuk bisa menikmati peningkatan kapasitas produksi ini dengan melakukan investasi baru. Jika perusahaan memperoleh dana yang besar membutuhkan perencanaan yang matang untuk membangun pabrik, membeli mesin baru memerlukan waktu yang cukup lama bukan dalam hitungan hari saja sehingga terdapat time lag yang cukup panjang antara saat revaluasi dilakukan dengan dampaknya kepada penjualan perusahaan dan economic growth (dampak kepada perpajakan juga serupa, revaluasi tahun 2015 tidak serta merta akan memengaruhi penerimaan di 2016), mungkin butuh 2-3 tahun untuk bisa menikmati peningkatan kapasitas produksi tersebut. Penurunan tarif pajak final dari aturan sebelumnya yang dikeluarkan oleh pemerintah dengan tarif awal $10 \%$ menjadi 3\% tidak memberikan dampak yang berarti terkait penghematan pajak karena perusahaan diwajibkan untuk membayar pajak final tersebut di awal pada saat perusahaan mengajukan revaluasi ke kantor pajak. Hal ini berdampak pada cash flow perusahaan. Selain pajak final yang dibayarkan perusahaan juga harus membayar biaya lainnya terutama biaya atas jasa penilai (appraisal) yang cukup mahal dan hal ini konsisten dilakukan secara teratur jika perusahaan menggunakan metode revaluasi atas aset tetap setiap minimal 3 atau 5 tahun. Revaluasi aset juga akan menambah beban baru seperti pembayaran pajak final atas revaluasi tersebut dan biaya penilai serta kemungkinan pemberian insentif kepada manajemen perusahaan akibat kenaikan laba komprehensif setelah melakukan revaluasi dan dengan pembayaran pajak final terlebih dahulu menyebabkan saldo cash operating berkurang dan perusahaan mempertimbangkan juga time value money.

\section{KESIMPULAN}

Penelitian ini menunjukkan bahwa tidak ditemukan perbedaan yang signifikan kinerja keuangan terkait rasio Debt to Equity Ratio (DER), Operational Profit Margin (OPM), Total Aset Turnover (TATO), Return on Assets (ROA) sebelum dan sesudah perusahaan melakukan revaluasi aset tetap. Hal ini disebabkan karena beberapa perusahaan yang melakukan revaluasi aset tetap hanya sekedar untuk memenuhi target dari pemerintah terkait pemenuhan target penerimaan pajak. Revaluasi sebenarnya menyebabkan bertambahnya nilai buku aset tetapi revaluasi sebenarnya tidak menambah fisik aset sehingga hal ini tidak mempengaruhi keuntungan yang dicapai perusahaan atau kenaikan pada operating profit margin perusahaan. Penghematan pajak tidak memiliki dampak yang signifikan karena mungkin saja ada dampak lain yaitu perusahaan harus terlebih dahulu untuk melakukan pembayaran atas pajak finalnya sehingga menyebabkan saldo cash operating berkurang dan perusahaan juga mempertimbangkan time value money. Biaya jasa penilai (appraisal) yang cukup mahal dan membutuhkan waktu yang lama dalam proses penilaian 
kembali aset sebagai salah satu dampak. Peningkatan aset yang direvaluasi menyebabkan biaya penyusutan yang meningkat sehingga menyebabkan laba perusahaan menurun tetapi tidak berdampak besar terhadap penghematan pajak.

Penelitian ini memiliki keterbatasan karena periode penelitian ini adalah periode 2 tahun penelitian sebelum dan sesudah perusahaan melakukan revaluasi aset tetap dimana tahun dasar yang digunakan tahun 2015 dan keterbatasan lain adalah tidak memperhitungkan pajak tangguhan yang timbul saat perusahaan melakukan revaluasi aset tetap dan sampel yang diambil tidak termasuk perusahaan yang bergerak di bidang perbankan dan lembaga keuangan lain seperti asuransi dan sekuritas. Penelitian ke depan bisa memasukkan variabel kontrol lain seperti dampak ke harga saham atau melihat future cash flow kedepan dan mungkin secara detail melihat tujuan dari masing-masing perusahaan apa yang memotivasi perusahaan melakukan revaluasi. Selain itu mungkin untuk penelitian berikutnya bisa juga melihat dampak revaluasi aset tetap untuk memperpanjang periode observasi penelitian misalnya menggunakan 5 tahun periode penelitian. Hal ini disebabkan karena adanya efek penyusutan atas tambahan revaluasi yang mempunyai umur baru yaitu antara 4-16 tahun kedepan.

\section{DAFTAR PUSTAKA}

Aboody, D, Barth, M. E. and R. Kasznik, 1999, Revaluation of Fixed Assets and Future Firm Performance: Evidence from the UK. Journal of Accounting and Economics, Vol. 26, $149-178$.

Annisa, 2017, Pengaruh Return on Asset, Leverage, Ukuran Perusahaan dan Koneksi Politik terhadap Penghindaran Pajak, JOM Fekom, Vol. 4, No.1.

Azouzi, M.A., and Jarboul, A., 2012, The Evidence of Management Motivation To Revalue Property Plant And Equipment In Tunisia, Journal of Accounting and Taxation, 4(2). https://doi.org/10.5897/JAT11.017.

Barac, Z. A. and Sodan, S., 2011, Motives for Asset Revaluation Policy Choice In Croatia. Croatian Operational Research Review (CRORR),2.

Brown, P, Izan, H. and Loh, A., 1992, "Fixed Asset Revaluations and Managerial Incentives", Abacus, Vol. 28, No.1, 36-57.

Fachrina, H., 2017, Perencanaan Pajak Melalui Revaluasi Aset Tetap Sebagai Upaya Penghematan Pajak Penghasilan, Jurnal Universitas Brawijaya. Malang, Thesis, http://repository.ub.ac.id/id/eprint/4389.

Fahmi, I., 2014, Analisis Laporan Keuangan, Bandung: Penerbit Aflabeta. 
188 Akuntansi Bisnis dan Manajemen, Vol. 26, No. 2, Oktober 2019

Gitman, L. J \&Zutter, C. J., 2012, Principles of Managerial Finance, Global Edition: Pearson Education Limited.

Horne, Van J. C and Wachowicz, Jr., J. M., 2013, Prinsip-prinsip Manajemen Keuangan, Edisi 13, Dialihbahasakan oleh Quratul'ain Mubarakah Jakarta: Penerbit Salemba Empat.

http://iaiglobal.or.id/v03/berita-kegiatan/detailarsip-864

Ikatan Akuntan Indonesia, 2016, "Pernyataan Standar Akuntansi Keuangan", Jakarta, Divisi Penerbitan IAI.

Manihuruk, T. N. fH \& Farahmita, A., 2015, Analisis Faktor-Faktor yang Mempengaruhi Pemilihan Metode Revaluasi Aset Tetap pada Perusahaan yang Terdaftar Di Bursa Saham Beberapa Negara Asean, Simposium Nasional Akuntansi 18, Medan: Universitas Sumatera Utara.

Peraturan Menteri Keuangan Republik Indonesia Nomor 79/PMK.03/2008 tentang Penilaian Kembali Aset Perusahaan untuk Tujuan Perpajakan, Jakarta.

Peraturan Menteri Keuangan Republik Indonesia Nomor 191/PMK.010/2015 tentang Penilaian Kembali Aset Perusahaan untuk Tujuan Perpajakan bagi Permohonan yang Diajukan pada Tahun 2015 dan Tahun 2016, Jakarta.

Peraturan Menteri Keuangan Republik Indonesia Nomor 233/PMK.03/2015 tentang Perubahan Atas Peraturan Menteri Keuangan Nomor 191/PMK.03/2015 tentang Penilaian Kembali Aset Perusahaan untuk Tujuan Perpajakan bagi Permohonan yang Diajukan pada Tahun 2015 dan Tahun 2016, Jakarta.

Piera, M. F., \& Hirsch, A. B, (n.d.), Motives for Fixed Asset Revaluation : an Empirical Analysis With Swiss Data, Journal of Business Finance and Accounting, Vol. 34, No. 7-8, 1025-1050.

Musyarrofah, E. (2017). Pengaruh Kepemilikan Manajerial, Leverage, dan Size Terhadap Cash Effective Tax Rate. Jurnal Ilmu Dan Riset Akuntansi, Vol. 6, No.9.

Seng, D., \& Su, J., 2010, Managerial Incentives Behind Fixed Asset Revaluations: Evidence from New Zealand Firms, International Journal of Business Research, Vol. 10, No.2.

Sherlita, E., Sari, D., \& Permana, Y. R. P., 2012, Pengaruh Negosiasi Debt Contracts Terhadap Perusahaan untuk Melakukan Revaluasi Aset Tetap dan Implikasinya Terhadap Biaya Pajak Penghasilan, Vol.7, 627-640. Universitas Kristen Satya Wacana. Retrieved from http://repository.library.uksw.edu/handle/123456789/1277.

Soenarno., 2013, Analisis Faktor-Faktor Yang Mempengaruhi Tarif Pajak Efektif. Jurnal Akuntansi Bisnis, Vol.10, No.2.

Suandy, E., 2011, Perencanaan Pajak, Jakarta: Salemba Empat. 
Suyani, 2017, Apakah Ketentuan Pajak Penghasilan Atas Revaluasi Aset Tetap Sejalan Dengan Konvergensi Ifrs?, Jurnal Pajak Indonesia, Vol.1, No.1, 76-91

Taufik dan Hanif, 2017, Pengaruh Return on Asset, Leverage, Ukuran Perusahaan Dan Koneksi Politik Terhadap Penghindaran Pajak. JOM Fekon, Vol 4, No.1, 685-698.

Whittered, G., \& Chan, Y.K., 1992, Asset Revaluations and the Mitigation of Underinvestment. Abacus, Vol. 28, No.1, 58-74, https://doi.org/10.1111/j.1467-6281.1992,tb00269.x.

Wijaya, S., \& Supandi, A. B., 2017, Analisis Revaluasi Aktiva Tetap pada PT Indonesia Power. Jurnal Pajak Indonesia, Vol 1, No.1, 106-117.

Yulistia, R., Popi, F., Arie F. M., \&Adzkya, K., 2015, Pengaruh Leverage, Arus Kas Operasi, Ukuran Perusahaan dan Fixed Asset Intensity Terhadap Revaluasi Aset Tetap, Simposium Nasional Akuntansi Vol. 18, No.20, https://doi.org/10.1016/j.jhsa.2014.07.008.

Hijriah, Almas, "Pengaruh Faktor Fundamental dan Risiko Sistematik Terhadap Harga Saham Properti di Bursa Efek Jakarta," Tesis, Universitas Sumatera Utara, Medan: 